DOI: $10.2478 /$ pof-2018-0034

VOLUME 10, ISSUE 3, 2018

ISSN: 2036-5438

\title{
Transnational Parliamentarism and the Dynamics of the IPC CFSP/CSDP:
}

\section{Policy-making, Accountability and Cooperation}

by

Kolja Raube and Daan Fonck*

Perspectives on Federalism, Vol. 10, issue 3, 2018 


\begin{abstract}
This contribution proposes a framework of transnational parliamentarism to study inter-parliamentary cooperation, and applies it to the interparliamentary conference on CFSP/CSDP. It asks to what extent the IPC's functioning reflects its constitutive intergovernmental logic, or whether its behaviour in practice might be guided by a transnational logic, hence becoming something more than just the parliamentary mirror of an intergovernmental cooperation framework. To this end we outline three functions that are brought forward by transnational parliamentarism: policy-making, collective accountability and cooperation, and investigate to which extent these logics can be observed in the functioning of the IPC CFSP/CSDP. Applying the framework reveals a nuanced picture of an inter-parliamentary cooperation framework which to some extent goes beyond purely intergovernmental functions of domestic accountability and representation, and also includes the performance of policy-making and parliamentary cooperation functions.
\end{abstract}

\title{
Key-words
}

IPC CFSP/CSDP, transnational parliamentarism, intergovernmental parliamentarism 


\section{Introduction}

In 2011, the long-awaited Interparliamentary Conference on the EU's Common Foreign and Security Policy and the Common Security and Defence Policy (IPC CFSP/CSDP) was established, succeeding earlier interparliamentary groupings overseeing the EU's foreign and security affairs. Designed to provide a parliamentary dimension for debating the intergovernmental European foreign and security policies, it brings together elected representatives from both the EU and Member state parliaments. This article turns to auditing the operative logic of the IPC CFSP/CSDP, by asking whether its functioning goes beyond mirroring its underpinning intergovernmental cooperation format by also displaying transnational interactions. In so doing, it discusses what the (potential) contribution of the IPC is, and how the IPC performs on these matters in practice.

While scholarly accounts have debated the conflicts of authority surrounding the set-up of the IPC (Herranz-Surrallés 2014), or how the IPC (potentially) addresses issues of accountability and democratic deficits in the EU's CFSP/CSDP (Wouters and Raube 2012; Buttler 2015), much less seems known about the logic underlying the praxis of the IPC CFSP/CSDP. Similarly, literature on inter-parliamentary cooperation that emerged over the last decade remains largely invested in democratic or legitimacy discourses on the one hand, or mapping exercises on the other hand; hence showing less interest in evaluating its actual performance as an actor. Addressing this gap, this article offers a novel framework for analysis, informed by transnationalist perspectives, to measure the operative logic of IPC.

The framework allows to audit the logic of transnational parliamentary cooperation on three different aspects: policy-making, accountability and cooperation. Applying the framework reveals a nuanced picture of an inter-parliamentary cooperation framework which to some extent goes beyond purely intergovernmental functions of domestic accountability, and also includes the performance of policy-making and parliamentary cooperation functions. In essence, while the literature has tried to make sense of this compromise and argue for and against the adequacy of institutional arrangements - none the least to fill the democratic gap of CFSP/CSDP (Cooper 2018) - our framework allows to focus on the transnational parliamentary effects and the actual institutional actorness 
(see Peters 2018). Time and again, we use the developments in IPC CFSP/CSDP, its documentation in primary and secondary sources as illustrations that support our proposed framework. By looking at policy-making, accountability and cooperation as effects of transnational interactions, we are also able to focus on the question of the added-value of parliamentary cooperation. A potential role of IPC CFSP/CSFP may thus be associated with parliamentary cooperation by including and going beyond questions of scrutiny and control.

\section{Inter-parliamentary cooperation and transnationalist perspectives}

When studying parliamentary involvement in European foreign policy, one is confronted with a highly-segmented literature that is structured by the scattered national, intergovernmental, and supranational agency that underlies this policy area (see Wagner 2015). Rarely, parliamentary fields have been studied in relation to one another, across levels and policy areas. The neglect of these cross-border links, connecting different parliamentary actors, is problematic since they have become more interwoven over time and appear to be in constant interaction (White 2004).

Corresponding to this challenge, over the last years, attention has been yielded to the rise of inter-parliamentary cooperation or 'multilayered parliamentarism' within and beyond the EU. Thus far, their contribution remains largely devoted to debates or theories on democracy, legitimacy and sovereignty on the one hand (e.g. Crum and Fossum 2013; Wouters and Raube 2016; Herranz-Surrallés 2014; Jančić 2015a), or to mapping or classification exercises on the other (e.g. Cofelice and Stavridis 2014; Kissling, 2011; De Vrieze 2015; Marschall 2016). A similar picture emanates from the current literature on the IPC CFSP/CSDP. Existing accounts have studied the conflicts of authority and sovereignty surrounding the set-up of the IPC (Herranz-Surrallés 2014), or how the IPC (potentially) addresses issues of accountability and democratic deficits in the EU's CFSP/CSDP (Wouters and Raube 2012; Buttler 2015). Yet, much less seems known about the logic underlying the praxis of the IPC CFSP/CSDP ${ }^{\mathrm{I}}$. To address this gap, we argue approaches are warranted that are primarily invested in identifying the operative logics that underpin cross-border parliamentary interactions, and the functions that emanate from such parliamentary cooperation networks. 
To this end, this article turns to the transnationalist literature. Originally introduced to the discipline of International Relations by Nye and Keohane, transnationalism has been described as 'contacts, coalitions, and interactions across state boundaries that are not controlled by the central foreign policy organs of governments' (Nye and Keohane 1971b: 331). The research agenda of transnationalism forced researchers to rethink which factors determined governments to take action, and to study the impact of NGOs and civil society organizations in international relations and norm-setting practices (Risse-Kappen 1997; Keck and Sikkink 1998).

Within European Studies, transnationalism has played an especially prominent role in transactionalist, intergovernmentalist, neo-functionalist and supranationalist approaches to integration (Hurrelmann 2011; Mau 2010; Fligstein and Stone Sweet 2002; Rosamond 2000), having all demonstrated how transnational forces contribute to explaining European integration. However, in terms of the actors studied, research has been limited to the study of either 'private' transnational civil society actors or transgovernmental actors. Remarkably, however, a transnational focus on interparliamentary cooperation remains underexposed (exceptions include legal approaches to transnationalism, such as von Bogdandy 2012; Jančić 2015b).

In this article, we attempt to fill this gap by studying the trans-parliamentary dimension of European foreign policy making. In that way, we broaden the scope of actors to parliamentary actors as a type of hybrid, societal-subgovernmental, actor (see also Peters 2018). Relying on insights from transnationalism, we ask what the nature and function of cross-border parliamentary relations mean and apply this to one specific cooperation framework: the IPC CFSP/CSDP. Established in 2011 as a cooperation framework in between EU Member State parliaments and the European Parliament, the IPC CFSP/CSDP has been meeting twice per year to debate and to exchange information or practices in the area of the Union's CFSP and CSDP. Making use of a transnational perspective, our aim is to understand if the IPC transcends its underpinning intergovernmental logic by evaluating the functions that emanate from these cross-border connections. 


\section{Transnational parliamentarism: a framework for analysis}

This section proposes a transnational approach to the study of inter-parliamentary cooperation. Operating on the border line between governmental and non-governmental spheres, transnational parliamentary actors or networks bear testimony to the widely acknowledged fact that clear-cut analytical distinctions between either state and non-state, public and private, or governmental and non-governmental actors, are not always mutually exclusive in reality (Agnew 1994; Josselin and Wallace 2001; Walker 1992). Instead, following Nye and Keohane, an actor's 'status' should be derived from its behaviour in practice, rather than from the formal position it occupies in a binary governmental vs. nongovernmental categorization scheme (Nye and Keohane 1971a: 733). Accordingly, transnational parliamentary behaviour is essentially manifested when parliamentary actors operate (semi-)autonomously across state boundaries, while 'not [being] controlled by the central foreign policy organs of governments' (Nye and Keohane 1971b: 331).

This yields the question what the exact purpose of such transnational parliamentarism is, and how it in fact goes beyond a mere parliamentary dimension of intergovernmental cooperation. How is transnationalism able to explain to establishment of interparliamentary networks, and the functions that these cross-border connections bring about? Two observations could be made in this regard. First, transnational avenues of action are generally opted for when domestic avenues to policy influence are constrained or result in limited impact (Risse-Kappen 1997; Keck and Sikkink 1999). Instead, it becomes more effective to bypass executive foreign policy organs and establish cross-border relations with foreign actors in order to generate impact on both domestic and foreign governments. For parliamentary actors, this implies that transnational strategies provide (additional) influence, when domestic mechanisms for steering and controlling executive foreign policy are considered unsatisfactory. This especially holds for opposition forces in parliament, which compared to majority members, are confronted with limited capacities to exercise strong influence over governmental foreign policy. However, within the domain of European foreign and security policy, the overall potential for transnational parliamentary interaction is very likely, given the strong executive prerogatives on both national and EU-levels (see also Wagner 2015: 366). 
Second, the type of activities performed by transnational actors is an extension of their internal or 'domestic' functions (Keck and Sikkink 1999: 99). This would imply that the functions performed by transnational parliamentarism are inextricably linked to the constitutional (or treaty-based) tasks of parliamentary actors such as debating, scrutinizing, legislating, and seeking accountability.

Further building on Jančić' (2015b), we hence define transnational parliamentarism as the cross-border investment of political capital from a parliamentary actor, while not being controlled by its domestic executive organs, with the purpose of contributing to policymaking, accountability and cooperation. Transnational parliamentarism hence goes beyond intergovernmental parliamentarism based on the functions of domestic accountability and representation, by enabling the pursuit of three distinctive functions: policy-making, accountability and cooperation (see Table 1).

Table 1: Functions of transnational parliamentarism

\begin{tabular}{|c|c|c|}
\hline & What & How \\
\hline $\begin{array}{l}\text { Policy- } \\
\text { making }\end{array}$ & $\begin{array}{l}\text { agenda-setting strategies and direct } \\
\text { involvement in decision-making } \\
\text { processes }\end{array}$ & $\begin{array}{l}\text { adopting recommendations or resolutions, } \\
\text { consultation rights, proposing legislative acts, giving } \\
\text { consent to decisions of the executive. }\end{array}$ \\
\hline Accountability & $\begin{array}{l}\text { monitoring governmental policies } \\
\text { and enforcing their compliance }\end{array}$ & through direct scrutiny \\
\hline Cooperation & implementation of foreign policy & $\begin{array}{l}\text { supportive or competitive types of parliamentary } \\
\text { diplomacy vis-à-vis EU diplomacy }\end{array}$ \\
\hline
\end{tabular}

\subsection{Policy-making}

A first function performed by transnational parliamentarism is that of policy-making. The involvement in a policy-making process could either occur indirectly, through agendasetting strategies, or directly through obtained rights of involvement in the policy-making process. First, agenda-setting 'requires an ability to capture public attention, frame issues in politically powerful ways, gather and disseminate information, and formulate appropriate ways to proceed' (Abbott and Snidal 2009: 21). One of the most straightforward functions of parliamentary actors in inter-parliamentary cooperation is that of generating public debate and deliberation (Lord 2013; Crum and Fossum 2009). By the very act of publicly debating issues, speech acts are performed, issues are framed and made salient, picked up 
by other actors; thus the more likely they will be put on the agenda of governmental agents (Peters 2018). It most often takes place through the adoption of resolutions, statements or recommendations.

Beyond the power to set the agenda of the executive, some transparliamentary organs have obtained direct involvement in decision-making processes. This capacity could range from the mere right to be consulted before a decision is taken, to the power to propose draft legislative acts which are then submitted to a ministerial level, or to a competence of giving consent to decisions of the executive.

\subsection{Accountability}

A second key function of transnational parliamentarism is that of ensuring accountability through monitoring governmental policies and enforcing compliance with declared policy engagements. One way this can be achieved, is through parliamentary scrutiny, which in principle can take place in two different ways: indirectly (domestic scrutiny) and directly (transnational scrutiny).

Indirect scrutiny, associated with intergovernmental parliamentarism, concerns the use of information derived from transnational parliamentary exchanges, in order to (better) exert scrutiny at home. Engaging with peers from other parliaments or with other foreign actors may serve as a means to overcome domestic information asymmetries between parliament and government, and especially persist in the international negotiation and decision-making (Zürn 2004). Overall, intergovernmental parliamentarism can be seen as serving input for domestic parliamentary scrutiny and control (cf. Crum and Fossum, 2013; Raunio, 2009: 322). Direct scrutiny, by contrast, occurs when trans-parliamentary exchange creates an opportunity for collectively controlling and overseeing the actions of overarching governance structures and decision-making in transnational fora, hence providing the means for collective accountability beyond domestic parliamentary settings.

\subsection{Cooperation}

Finally, transnational parliamentarism may also enable cooperation beyond intergovernmental networks, often labelled as parliamentary diplomacy (Stavridis 2002; Cutler 2006; Weisglas and de Boer 2007; Stavridis and Jančić 2016; Fonck, 2018b). A crucial question in that regard is whether parliamentary diplomats assist with implementing 
pre-defined foreign policy goals of their governments, or, rather, whether they pursue their own interests, regardless of what governmental actors desire. Accordingly, one could discern both supportive and competitive types of parliamentary diplomacy (Fonck 2018a).

Supportive parliamentary diplomacy primarily serves to contribute to the implementation of (inter-) governmental policies and interests through parliamentary channels of influence. It could serve a specific (intergovernmental) policy or issue-oriented goals through mediation, trust-building or reconciliation (Beetham 2006; Malamud and Stavridis 2011), but might also be focused at wider, long-term processes of socialisation and norm diffusion through exchanging ideas or best practices (Petrova and Raube 2016). A competitive parliamentary diplomacy concerns a more independent undertaking, serving an autonomous transnational parliamentary agenda and therefore might complicate governmental foreign policy (Malamud and Stavridis 2011: 105). The strategy through which parliamentary actors operate is mostly focused at creating precedents, aimed at entrapping governmental actors and altering their degree of freedom in the making of foreign policy decisions.

\section{Decision-making, accountability and cooperation in the Interparliamentary Conference on CFSP/CSDP}

\subsection{Applying transnational parliamentarism to IPC CFSP/CSDP}

As it has been described elsewhere (Wouters and Raube 2012, 2016), the IPC CFSP/ CSDP has been established based on Article 10 of Protocol 1 annexed to the Treaty of Lisbon. Article 10 mentions that COSAC can 'also organise interparliamentary conferences on particular issues'. In fact, the establishment of the IPC CFSP/CSDP as an intergovernmental or transnational parliamentary endeavour can perhaps be best understood with the 'unfinished democratization of Europe' (Eriksen 2011).

The Lisbon Treaty did not solve if and how intergovernmental policy areas, such as CFSP/CSDP could be best legitimized and controlled. While at the outset, CSFP/CSDP is intergovernmental, the ways how national parliaments can control decisions made on the European level, greatly differ. Hence, we see an asymmetrical situation with some national parliaments having larger influences (prerogatives) than others on a horizontal playing field, while - at the same time - the European Parliament lacks formal powers that (some) 
national parliaments have (Raube and Wouters 2017). In such a context, three options arise institutionally: to democratize or (at least) parliamentarise CFSP/CSFP through a creeping expansion of informal (and formal) powers of the European Parliament (Rosén and Raube 2018; Lord 2016), to simply call the role of the European Parliament 'symbolic' (RipollServent 2018) and leave powers to control and oversee CFSP/CSDP to the Member State level, e.g. the national parliaments, or to look for a third way: an interparliamentary cooperation which tries to fill the gap of unfinished democratization that the Lisbon Treaty has left behind.

Despite such theoretical considerations the actual trigger to create an interparliamentary forum in CFSP/CSFD must be seen in the ceasing of the Western European Union (WEU) Assembly whose establishing treaty was not renewed by its Member States in 2011 for financial reasons. But the Member States did not let the Parisbased WEU Assembly die before making a last wish on its behalf: 'to encourage [...] interparliamentary dialogue [...] in this field...' (cited in: Wouters and Raube 2016: 236). What followed has been discussed at length in the academic debate (see Peters 2018), and, basically, ended with a compromise, on how the new Interparliamentary Conference CFSP/CSFP would set-up, used and run in the context in CFSP/CSDP. In short, it allows 16 MEPs and 6 MPs from each Member State to come together and debate, to 'provide a framework for the exchange of information and best practices', to draft conclusions after consent on issues related to CFSP/CSDP, and to organise itself without a secretariat in a spirit of cooperation between the European Parliament and the respective presiding Member State parliament. In essence, while the literature has tried to make sense of this compromise and argue for and against the adequacy of institutional arrangements - none the least to fill the democratic gap of CFSP/CSDP (Cooper 2018) - we may ask what is in this compromise and the actual practice of IPC CFSP/CSFP, once we look at it through our framework of 'intergovernmental vs. transnational' parliamentarism. In fact, such a move allows us to focus on the intergovernmental and transnational parliamentary effects and the actual institutional actorness (see Peters 2018). By looking at policy-making, accountability and cooperation as effects of parliamentary interactions we are also able to steer our focus to the question of the added-value of parliamentary cooperation. A potential role of IPC CFSP/CSFP may thus be associated with parliamentary cooperation by including and going beyond questions of scrutiny and control. It is in this context that 
we also look at features such as policy-making and cooperation (see Peters 2018, for a similar, and yet, different framework focusing on 'actor, network, symbol').

\subsection{Policy-making}

We argued above that the involvement in a policy-making process could either occur indirect, through agenda-setting strategies, or directly through obtained rights of involvement in the policy-making process. In what follows, we try to show if direct (transnational) or indirect (intergovernmental) logics apply to the IPC CFSP/ CSDP.

In our effort to find out if transnational or intergovernmental parliamentary logics apply, we have to remember that the IPC CFSP/CSDP is neither a parliamentary assembly, nor a third chamber in the EU. Its rights to be directly involved are, in fact, limited to a non-parliamentary decision-making procedure, informed by international consensual decision-making. In essence then, the IPC is run by an intergovernmental rather than a transnational logic of sovereignty-prevailing consensus-making. This element is, for example, underlined by the fact that the 'conference' drafts final conclusions, which are adopted by consensus. Furthermore, in an analogy to Declaration 13 and 14 to the Treaty of the European Union, which have been seen as the expression of intergovernmentalism par excellence in CFSP/CSDP, the rules of procedure of IPC CFSP/CSDP foresee that its conclusions 'do not bind' nor 'prejudge' any national parliament (nor European Parliament) in its position (article 1.4). Nevertheless, in contrast to these rules, we see elements of transnational parliamentary cooperation, including fixed proportionate delegation sizes, depending whether you are belong to the EP or a national parliament $(16+6)$. As it has been argued elsewhere, the question whether such fixed and proportionate delegation sizes are really useful, as long as consensus-decision-making is in place (Wouters and Raube 2016).

The IPC CFSP/CSDP has been working with a rotating presidency. Again, IPC CFSP/CSDP copies an intergovernmental logic, which limits a transnational agenda-setting strategy from taking place. The country presidency changes every six months and is the same that presides over the rotating institutions of the rest of the European Union. There is no centrally organized secretariat that the presidency works together with, rather a cooperative mechanism between the presiding national parliaments and the European Parliament who agree on upcoming conference agendas (Cooper 2018). While 
CFSP/CSDP has itself established a decision-making procedure within which the HR/VP CFSP/CSDP not only presides permanently over the Foreign Affairs Council and can initiate policy-proposals within CFSP/CSDP, the IPC CFSP/CSDP is still run according to the pre-Lisbon mode, when it were the Member States which presided over the Council. The effect is that transnational interaction of parliaments may well happen in the conferences, but that inter-parliamentary coordination prior to the conferences is limited to the informal exchanges between the presiding national parliament and the European Parliament. In fact, agenda-setting in the IPC CFSP/CSDP shows signs of compromise between the interest of the presiding national parliament to bring themes to the fore that are of crucial domestic and regional importance for the respective Member State and those topics put forward by the European Parliament, which very often tries to address themes that are currently high on the agenda of the Council (e.g. Stavridis and Gianniou 2015).

The non-existence of binding decisions, nor conclusions as well as the rotating presidencies have an effect on the 'teeth' of the inter-parliamentary conference. The transnational policy- and agenda-making function of the conference is clearly limited by its non-binding nature. On the one hand it rules out that the IPC CFSP/CSDP can become a competing 'third chamber' on the European Union level next to national parliaments and the European Parliament. On the other hand, it safeguards the sovereignty of any of the parliaments involved in the conference. Moreover, as long as the conference does not develop some kind of binding nature, it appears difficult to exert credible authority over ongoing CFSP/CSDP debates in a consistent manner over time. Its capacity to influence CFSP/CSDP decision-making by pro-active conclusions, in the same manner how the European Parliament issues own-initiative resolutions, is inhibited by a risk of undermining itself by the non-binding nature of the text. Moreover, it should be noted that, the IPC $\mathrm{CFSP} / \mathrm{CSDP}$ is not able to instrumentalise its consent powers in other policy areas to get a foot in the door in the area of CFSP/CSDP, in a way the European Parliament often does. However, as practice shows the actors within the conference, including the European Parliament, have well made use of the work of IPC CFSP/CSDP by constantly referring to its conclusions in its own CFSP/CSDP related resolutions. 


\subsection{Accountability}

As explained above, transnational parliamentarism can well contribute to democratic accountability by monitoring governmental policies and enforcing compliance with declared policy engagements. We argued that this can be achieved through direct transnational scrutiny beyond the national domestic settings. In this respect, Wagner speaks off the 'democratic rationale' of IPCs, especially in the context of multi-level governance and the inclusion of national and supranational parliaments (2018). Indeed, as shown by Peters (2018), the number of guest speakers in the IPC CFSP/CSDP has grown considerably over the years of its existence. This could indicate in increased effort of the IPC to exercise direct scrutiny by using the forum to interrogate policy-makers of CFSP/CSDP. In fact, it was also shown that especially the HR/VP can be invited to the meetings of the conference (article 2.3). With minor exceptions, the HR/VP has taken the chance to follow the invitation of IPC CFSP/CSDP and in the review of the conference, the 'consistent participation' of the HR/VP is seen as a meaningful way to generate debate about the policy's priorities and strategies (Wouters and Raube 2016).

It should be highlighted, however, that the appearance of personnel is often related to the exchange of information rather than the scrutiny of the CFSP/CSDP related staff. One element related to this may also be the absence of a tool that would enable the IPC CFSP/CSDP to actually scrutinize decision-makers in the absence of formal control mechanisms: neither does the IPC have the opportunity to scrutinize personnel and their policies through issue-linkage (see, in the case of the EP, Rosén and Raube 2018), nor has it itself developed tools, such as binding conclusions, resolutions or policy reports, by which it can remind staff of their obligations and duties. The lack of formality can in this regard be seen as undermining transnational control and scrutiny (see also Wouters and Raube 2016).

Furthermore, the absence of a proper public sphere around the IPCs does not help the transnational scrutiny effort. Only in recent years, the IPCs are getting live-streamed, yet they do not have an active online audience, let alone an extensive social media outreach. Similar as to the interparliamentary online platform IPEX, these remain useful tools to inform experts and involved personnel in the field about agendas, speeches and conclusions, but it remains difficult to access for a wider audience. 
As regards indirect scrutiny, however, the European Parliament started to use nonbinding resolutions of the IPC CFSP/CSDP to back-up its own self-initiated reports as a way to scrutinize CFSP/CSDP related personnel, including the HR/VP. The presence of almost all members of the EP throughout the last sessions of IPC CFSP/CSDP can be interpreted as the EP's willingness to engage, but also to take home essential insights that can be used to its own benefit. Research still awaits to be done to prove if the same technique is used by national parliaments. However, a continuing lack of presence of certain national delegation members (see also Peters 2018) may be seen as undermining efforts to enable indirect scrutiny. Moreover, opposite to a lack of formal powers on the side of the European Parliament, which ask the supranational body to use other means to informally scrutinize CFSP/CSDP, national parliaments present more like a 'mixed bag' and different strategies how to hold their governments accountable. And yet, while there is a large body of literature on how national parliaments try to scrutinize of foreign policy, EU policies and CFSP/CSFP in particular (Fromage 2015; Jančić 2017; Mello/Peters 2018), further research needs to be done how exactly national parliaments make use of their participation in the IPC CFSP/CSDP to hold their own governments domestically accountable.

\subsection{Cooperation}

Transnational parliamentarism may also enable cooperation beyond intergovernmental networks, often labelled as parliamentary diplomacy. In the context of IPC CFSP/CSDP we may look at parliamentary diplomacy within the European Union. In an analogy to what has been called as 'European Union as a Diplomatic System' (Smith et al. 2016), we may look at parliamentary cooperation as a means of parliamentary diplomacy. While IPC CFSP/CSDP to this day lacks institutionalized diplomacy with external actors, amongst others due to the lack of a secretariat that would be able to establish such global transnational ties with other parliaments, interparliamentary assemblies and conferences, it has - as Peters has shown (2018) - clearly strengthened the transnational networking effect of national parliaments. This is supported by what Wagner calls the polemological rationale of IPCs (2018), i.e. the fostering of transnational relations through mutual parliamentary understanding, eventually contributing to international peace-building. 
Parliamentary diplomacy within the CFSP/CSDP IPC can be seen through its effects on problem-and awareness raising of national parliaments as well as the creation of a support culture for CFSP/CSDP. In fact, from a European Parliament perspective the overall goal was to persuade national parliaments of the need for CFSP/CSDP in the first place, that is, more strictly speaking, in the long-run the support for an ongoing cooperation of security issues on the European level and potentially the transfer of competences to the EU. The creation of a security culture and identity in CFSP/CSDP, a key-objective of the EU (Duke 2017; Howorth 2014), has also become a major ambition of the EP at the beginning of IPC CFSP/CSDP meetings (Wouters and Raube 2012). Today, the EP sees it as one of the major achievements of IPC CFSP/CSDP. Bi-annual meetings and reflections on various topics related to CFSP/CSDP have led to ongoing information exchanges in the field. While the conferences may not follow necessarily a consistent logic of themes and issues, the 'central corrective' in combination with a regular appearance of the HR/VP in the IPC CFSP/CSDP has enabled a steady flow of information. After a rough start in a 'parliamentary battlefield' (Herranz-Surrallés 2014), information exchanges kept flowing and contributed to the meaningful implementation of the conference over the first years. More research however should look into the extent to which there is an established mechanism of mutual understanding, including the understanding and taking into account of national parliamentary positions on the side of the European Parliament.

Overall, we can see however that parliamentary cooperation in IPC CFSP/CSDP has been used by parliaments to create a forum to develop supportive measures and identities in the context of CFSP/CSDP implementation.

\section{Conclusion}

This contribution has proposed a conceptual framework of transnational parliamentarism to measure the effectiveness of transnational parliamentary cooperation in the area of CFSP/CSDP on three different aspects: policy-making, accountability and cooperation. Applying the transnational parliamentarism framework has in fact revealed an image of an inter-parliamentary cooperation framework that goes beyond functions of scrutiny and control in theory: it also focused on policy-making and cooperation. By looking at policy-making, accountability and cooperation as potential effects of 
transnational interactions we found that the transnational effects of the IPC CFSP/CSFP were rather limited in the categories decision-making and accountability, due to the partially intergovernmental-setting and non-binding-format of the conference (see table 2). However we saw that especially the European Parliament made use of these functions in its work vis-à-vis CFSP/CSDP.

Table 2: Evaluating the performance of the IPC on CFSP/CSDP

\begin{tabular}{|l|l|l|}
\hline & Characteristics & Effectiveness \\
\hline Policy-making & Non-binding & \begin{tabular}{l} 
Limited, and yet used by the European Parliament \\
\hline Accountability
\end{tabular} Direct and indirect scrutiny \\
\hline Cooperation & $\begin{array}{l}\text { Mutual Understanding, } \\
\text { diplomacy }\end{array}$ & $\begin{array}{l}\text { Rather Effective on the side of the European } \\
\text { Parliament }\end{array}$ \\
\hline
\end{tabular}

In the last category - cooperation - we also found that the IPC CFSP/CSDP has especially shown effects for the European Parliament in its effort to strengthen a security and support culture around CFSP/CSDP in cooperation with other national parliaments.

Beyond accountability, IPC CFSP/CSDP is an interesting example of transnational parliamentarism. The article showed that the concept can be useful to test the effects of transnational interactions also in the field of established institutionalized cooperation with the European Union. At the same time, more research is needed to focus especially on the effects of transnationalism parliamentarism in the national parliamentary settings.

\footnotetext{
* Kolja Raube, Leuven Centre for Global Governance Studies, Leuven International and European Studies (LINES), University of Leuven, Leuven, Belgium (kolja.raube@kuleuven.be). Daan Fonck, Leuven International and European Studies (LINES), University of Leuven, Belgium (daan.fonck@kuleuven.be). I A clear exception in this regard is Peters (2018) who studies the practice of the IPC CFSP/CSDP on three different roles.
}

\section{References}

- Abbott Kenneth W. and Snidal Duncan, 2009, 'The Governance Triangle: Regulatory Standards Institutions and The Shadow of the State', in Mattli Walter and Ngaire Woods (eds) The Politics of Global Regulation, Princeton University Press, Princeton NJ, 44-88.

- Agnew John, 1994, 'The Territorial Trap: The Geographical Assumptions of International Relations Theory', Review of International Political Economy, I(1): 53-80.

- Beetham David, 2006, Parliament and democracy in the Twenty-first Century, Inter-Parliamentary Union/SRO-Kundig, Geneva. 
- $\quad$ Buttler Graham, 2015, 'The Interparliamentary Conference on the CFSP/CSDP: A new forum for the Oireachtas in Irish and EU foreign policy?', Irish Studies in International Affairs, XXVI: 163-186.

- Cofelice Andrea and Stavridis Stelios, 2014, 'The European Parliament as an International Parliamentary Institution (IPI)', European Foreign Affairs Review, XIX(2): 145-178.

- Crum Ben and Fossum John Erik, 2009, 'The Multilevel Parliamentary Field: a framework for theorizing representative democracy in the EU', European Political Science Review, I(2): 249-271.

- Crum Ben and Fossum John Erik (eds), 2013, Practices of Inter-parliamentary Coordination in International Politics: The European Union and Beyond, ECPR Press, Colchester.

- Cutler Robert M., 2006, 'The OSCE's Parliamentary Diplomacy in Central Asia and the South Caucasus in Comparative Perspective', Studia Diplomatica, XXIX(2): 79-93.

- De Vrieze Frank, 2015, Study on Parliamentary Cooperation: Mapping and Analysis of International Parliamentary Institutions and Parliamentary Networks in the Western Balkans and South East Europe, European Commission, Brussels.

- $\quad$ Duke Simon, 2017, Europe as a Stronger Global Actor, Palgrave Macmillan, Basingstole.

- $\quad$ Fligstein Neil and Stone Sweet Alec (2002) Constructing Polities and Markets: An Institutionalist Account of European Integration, American Journal of Sociology, CVII(5): 1206-1243.

- Fonck Daan, 2018a, 'Servants or Rivals? Uncovering the Drivers and Logics of the European Parliament's Diplomacy during the Ukrainian Crisis', in Raube Kolja, Meltem Müftüler \& Jan Wouters (eds) Parliamentary Cooperation and Diplomacy in EU External Relations, Edwar Elgar, Cheltenham.

- Fonck Daan, 2018b, 'Parliamentary Diplomacy and Legislative-Executive Relations in EU Foreign Policy: Studying the European Parliament's Mediation of the Macedonian Political Crisis (2015-2017)', JCMS: Journal of Common Market Studies, OnlineFirst.

- $\quad$ Fromage Diane, 2015, Les parlements dans l'Union européenne après le Traité de Lisbonne: la participation des parlements allemands, britanniques, espagnols, français et italiens, L'Harmattan, Paris.

- Herranz-Surrallés Anna, 2014, 'The EU's Multilevel Parliamentary (Battle)Field: Inter-parliamentary Cooperation and Conflict in Foreign and Security Policy', West European Politics, XXXVII(5): 957-975.

- Howorth Jolyon, 2014, Security and Defence Polity in the European Union, 2nd edition, Palgrave Macmillan, Basingstoke.

- Hurrelmann Achim, 2011, 'Transnationalism and the Theory of European Integration: Political Science Perspectives', in DeBardeleben Johan \& Achim Hurrelman (eds), Transnational Europe: Promise, Paradox, Limits, Palgrave Macmillan, Basingstoke.

- Jančić Davor (ed), 2017, National Parliaments after the Lisbon Treaty and the Euro Crisis, Oxford University Press, Oxford.

- Jančić Davor, 2015a, 'Globalizing Representative Democracy: The Emergence of Multilayered International Parliamentalism', Hastings International and Comparative Law Review, XXXVIII(2): 197-242.

- Jančić Davor, 2015b, 'Transnational Parliamentarism and Global Governance: The New Practice of Democracy', in Fahey Elaine (ed), The Actors of Postnational Rulemaking: Contemporary Challenges of European and International Law, Routledge, London.

- Josselin Daphné and Wallace William, 2001, 'Non-state Actors in World Politics: a Framework', in Josselin Daphné \& William Wallace (eds), Non-state Actors in World Politics, Palgrave Macmillan, Hampshire, 120.

- $\quad$ Keck Margaret E. and Sikkink Kathryn, 1998, Activists Beyond Borders, Cornell University Press, Ithaca and London.

- $\quad$ Keck Margaret E. and Sikkink Kathryn, 1999, 'Transnational advocacy networks in international and regional politics', International Social Science Journal, LI(159): 89-101.

- Kissling Claudia, 2011, The Legal and Political Status of International Parliamentary Institutions, Berlin, Committee for a Democratic U.N., Berlin.

- $\quad$ Lord Christopher, 2013, 'The European Union: Parliamentary Wasteland or Parliamentary Field?', in Crum Ben \& John Erik Fossum (eds), Practices of Inter-parliamentary Coordination in International Politics: The European Union and Beyond, ECPR Press, Colchester.

- Malamud Andrés and Stavridis Stelios, 2011, 'Parliaments and Parliamentarians as International Actors' in Reinalda Bob (ed), The Ashgate Research Companion to Non-State Actors, Ashgate, Surrey,101-115. 
- Marschall Stefan, 2016, Parlamentarismus. Eine Einführung, Nomos, Baden-Baden.

- Mau Steffen, 2010, Social Transnationalism. Lifeworlds beyond the nation-state, Routledge, London.

- Mello Patrick and Peters Dirk, 2018, 'Parliaments in security policy: involvement, politicisation and influence', British Journal of Politics and International Relations, XX(1): 3-18.

- Nye Joseph S. and Keohane Robert O., 1971a, 'Transnational Relations and World Politics: A Conclusion', International Organization, XXV(3): 721-748.

- Nye Joseph S. and Keohane Robert O., 1971b, 'Transnational Relations and World Politics: An Introduction', International Organization, XXV(3): 329-349.

- $\quad$ Peters Dirk, 2018, 'Actor, Network, Symbol: The IPC at Three', in Raube Kolja, Meltem Müftüler \& Jan Wouters (eds), Parliamentary Cooperation and Diplomacy in EU External Relations, Edward Elgar, Cheltenham.

- Petrova Irina and Raube Kolja, 2016, 'Euronest: What Drives Inter-Parliamentary Cooperation in the Eastern Partnership?', European Foreign Affairs Review, XXI(1): 35-55.

- Raunio Tapio, 2009, 'National Parliaments and European Integration: What We Know and Agenda for Future Research', The Journal of Legislative Studies, XV(4): 317-334.

- $\quad$ Risse-Kappen Thomas, 1997, Bringing Transnational Relations Back in. Non-State Actors, Domestic Structures and International Institutions, Cambridge University Press, Cambridge.

- $\quad$ Rosamond Ben, 2000, Theories of European Integration, Palgrave Macmillan, Basingstoke.

- Rosén Guri and Raube Kolja, 2018, 'Influence Beyond Formal Powers: The Parliamentarization of EU Security Policy', British Journal of Politics and International Relations, XX(1): 69-83.

- Stavridis Stelios, 2002, “Parliamentary Diplomacy": some preliminary findings', in Jean Monnet Working Papers in Comparative and International Politics, Catania, Department of Political Studies - University of Catania.

- Stavridis Stelios and Jančić Davor, 2016, 'Introduction: The Rise of Parliamentary Diplomacy in International Politics', The Hague Journal of Diplomacy, XI(2-3): 105-120.

- Stavridis Stelios and Gianniou Maria, 2015, 'The parliamentary dimension of EU external affairs during the 2014 Greek Presidency', ELIAMEP Working Paper No. 66, June.

- $\quad$ von Bogdandy Armin, 2012, 'The European Lesson for International Democracy: The Significance of Articles 9 to 12 EU Treaty for International Organizations', European Journal of International Law, XXIII(2): 315-334.

- Wagner Wolfgang, 2015, 'National Parliaments', in Jørgensen Knud Erik, Aarstad Aasne Kalland, Drieskens Edith et al. (eds), The SAGE Handbook of European Foreign Policy, Sage, London.

- Wagner Wolfgang, 2018, 'The logic of interparliamentary cooperation in security policies', in Raube Kolja, Meltem Müftüler \& Jan Wouters (eds) Parliamentary Cooperation and Diplomacy in EU External Relations, Edwar Elgar, Cheltenham.

- Walker Rob BJ., 1992, Inside/Outside: International Relations as Political Theory, Cambridge University Press, Cambridge.

- Weisglas Frans F. and de Boer Gonnie, 2007, 'Parliamentary Diplomacy', The Hague Journal of Diplomacy, II(1): 93-99.

- Wouters Jan and Raube Kolja, 2012, 'Seeking CSDP Accountability Through Interparliamentary Scrutiny', The International Spectator, XLVII(4): 149-163.

- Wouters Jan and Raube Kolja, 2016, 'The many facets of parliamentary involvement and interaction in EU external relations', in Lupo Nicola \& Cristina Fasone (eds), Interparliamentary Cooperation in the Composite European Constitution, Hart, Oxford.

- Zürn Michael, 2004, 'Global Governance and Legitimacy Problems', Government and Opposition, XXXIX(2): 260-287. 